\title{
Introduced macroalgae - A growing concern
}

\author{
Britta Schaffelke ${ }^{1, *}$, Jennifer E. Smith ${ }^{2} \&$ Chad L. Hewitt ${ }^{3}$ \\ ${ }^{1}$ CRC Reef Research Centre and James Cook University, PO Box 772, Townsville QLD 4810, Australia; Current \\ address: Australian Institute of Marine Science, PMB 3, Townsville MC QLD 4810, Australia; ${ }^{2}$ Department of \\ Botany, University of Hawaii Manoa, 3190 Maile Way, Honolulu, HI 96822, USA; Current address: University of \\ California, 735 State St., Santa Barbara, CA 93101, USA; ${ }^{3}$ Ministry of Agriculture and Forestry, Biosecurity New \\ Zealand, PO Box 2526, Wellington 6001, New Zealand; Current address: National Centre for Marine and Coastal \\ Conservation, Australian Maritime College, Private Bag 10, Rosebud VIC 3939, Australia
}

*

Key words: introduced species, invasion biology, invasive macroalgae

\begin{abstract}
Introductions of non-indigenous species to new ecosystems are one of the major threats to biodiversity, ecosystem functions and services. Globally, species introductions may lead to biotic homogenisation, in synergy with other anthropogenic disturbances such as climate change and coastal pollution. Successful marine introductions depend on (1) presence of a transport vector, uptake of propagules and journey survival of the species; (2) suitable environmental conditions in the receiving habitat; and (3) biological traits of the invader to facilitate establishment. Knowledge has improved of the distribution, biology and ecology of high profile seaweed invaders, e.g. Caulerpa taxifolia, Codium fragile ssp. tomentosoides, Sargassum muticum, and Undaria pinnatifida. Limited, regional information is available for less conspicuous species. The mechanisms of seaweed introductions are little understood as research on introduced seaweeds has been mostly reactive, following discoveries of introductions. Sources of introductions mostly cannot be determined with certainty apart from those directly associated with aquaculture activities and few studies have addressed the sometimes serious ecological and economic impacts of seaweed introductions. Future research needs to elucidate the invasion process, interactions between invaders, and impacts of introductions to support prevention and management of seaweed introductions.
\end{abstract}

\section{Introduction}

Introduced species are considered to be one of the greatest threats to native marine biodiversity and resource values of the world's oceans (Norse, 1993; Vitousek et al., 1997; Carlton, 2000). Regional studies have identified hundreds of non-indigenous marine species (NIMS) introduced through human activities. These studies are, however, limited to a few countries or regions, i.e. Australia, Europe, New Zealand and the United States (e.g. Pollard \& Hutchings, 1990; Cohen \& Carlton, 1995; Cranfield et al., 1998; Coles et al., 1999; Ruiz et al., 2000; Hewitt et al., 2004). There is very little information on the status of NIMS in other regions (e.g. Williamson et al., 2002 for 20 member economies of the Asia-Pacific Economic Cooperation, APEC). The rate of introductions of NIMS has increased in the last 20 years, reflecting increased global trade but also more survey effort (Ruiz et al., 2000; Ribera Siguan, 2002; Hewitt, 2003a). Some NIMS have had catastrophic effects on the recipient ecosystem, e.g. the Asian clam (Potamocorbula amurensis) in San Francisco Bay (Nichols et al., 1994) and the comb jelly (Mnemiopsis leidyi) in the Black Sea (Kideys, 2002). The combined effects of global change and species introductions are believed to result in biotic homogenization (e.g., Olden et al., 2004; Olden and Poff, 2004; Wilkinson, 2004). Widespread generalists and opportunistic species will dominate ecosystems, a pattern already observed in locations affected by environmental 
Table 1. Number of non-indigenous marine species (NIMS) introduced to various regions.

\begin{tabular}{|c|c|c|c|c|}
\hline Location & Total extant NIMS & Macroalgal NIMS (no.) & Macroalgal NIMS (\%.) & Reference \\
\hline French Atlantic Coast & 104 & 21 & 20 & Goulletquer et al. (2002) \\
\hline Italy & 110 & 32 & 29 & Occhipinti Ambrogi (2002) \\
\hline North Sea coast & 82 & 20 & 24 & Reise et al. (2002) \\
\hline Chile & 32 & 12 & 38 & Castilla et al. (in press) \\
\hline Hawaii & 89 & 21 & 24 & $\begin{array}{l}\text { Coles et al. (1999), Godwin (2001) } \\
\text { and Smith et al. (2002) }\end{array}$ \\
\hline New Zealand & 109 & 19 & 17 & Cranfield et al. (1998) \\
\hline Port Phillip Bay, Australia & 99 & 16 & 16 & Hewitt et al. (2004) \\
\hline United States (continental) & 298 & 24 & 8 & Ruiz et al. (2000) \\
\hline
\end{tabular}

degradation, and likely to be amplified by species introductions (McKinney \& Lockwood, 1999).

Marine macroalgae are a significant component of introduced NIMS (Table 1). These include several high profile species that have caused significant ecological and economic impacts (e.g. Caulerpa taxifolia (Vahl) C. Agardh, Codium fragile (Suringar) Hariot ssp. tomentosoides (Van Goor) Silva, Sargassum muticum (Yendo) Fensholt and Undaria pinnatifida (Harvey) Suringar; e.g. Trowbridge, 1998; Boudouresque \& Verlaque, 2002; Ribera Siguan, 2002, 2003; Wallentinus, 2002; Occhipinti-Ambrogi \& Savini, 2003). Macroalgae are considered to be especially worrying NIMS as they may alter both ecosystem structure and function by monopolizing space, developing into ecosystem engineers, changing foodwebs, and spreading beyond their initial point of introduction through efficient dispersal capacities (Thresher, 2000).

The majority $(80 \%)$ of marine macroalgal orders contain introduced species: 7 out of 9 orders in the phylum Chlorophyta, 16 out of 19 orders in the Rhodophyta, 8 out of 12 orders in the Phaeophyceae. The numbers of introduced species per order are highly correlated with total species number (Figure 1, Pearson-Product moment correlation: $r^{2}=0.91$, $p<0.05)$. However, some orders contain more, others less, introduced species than expected by chance alone; for example the Ectocarpales, Laminariales and Bonnemaisoniales have more, while the Chaetophorales, Fucales and Corallinales have less introduced species than expected (Smith et al., unpublished data).

Recent reviews of the status of introduced marine plants, both with a regional and global scope, include current inventories of introduced species as well as assessments of introduction vectors and mechanism that may influence invasion success (Wallentinus, 1999a,
2002; Verlaque, 2001; Ribera Siguan, 2002, 2003; Smith et al., 2002). Despite recent research, especially in the Pacific region and the Mediterranean Sea, we still have a limited understanding of the invasion process, the distribution and ecology of less conspicuous introduced macroalgae, and the ecological and economic impacts of marine invasions. In this review we will update current knowledge of seaweed introductions using recent case studies to illustrate the three main phases of the invasion process: uptake and transport, release and establishment, and spread and impact.

\section{Uptake and transport}

The first stage in the invasion process depends on the presence of a transport vector and the availability of suitable macroalgal life stages for uptake by this vector. The most important pathways for the transport of NIMS are associated with shipping vectors (ballast water and fouling of hulls), aquaculture and the aquarium trade (Ruiz et al., 2000; Carlton, 2001; Hewitt et al., 2004). It is often difficult to pinpoint a pathway for a specific introduction; it may differ between regions or the introduction may have occurred through multiple pathways.

Fouling of ships' hulls, structures or other surfaces and living epibiotically (e.g., on mollusks) or as boring organisms (e.g., the conchocelis phase of Porphyra species boring into mollusk shells) are considered to be the most important pathways for the unintentional introduction of macroalgae (Ribera Siguan, 2003). All macroalgae have the potential to colonise ships' hulls and other maritime structures, especially species that occur either within or in close proximity to port environments. In Port Phillip Bay, Australia, fouling of ships' hulls is considered to be the most 


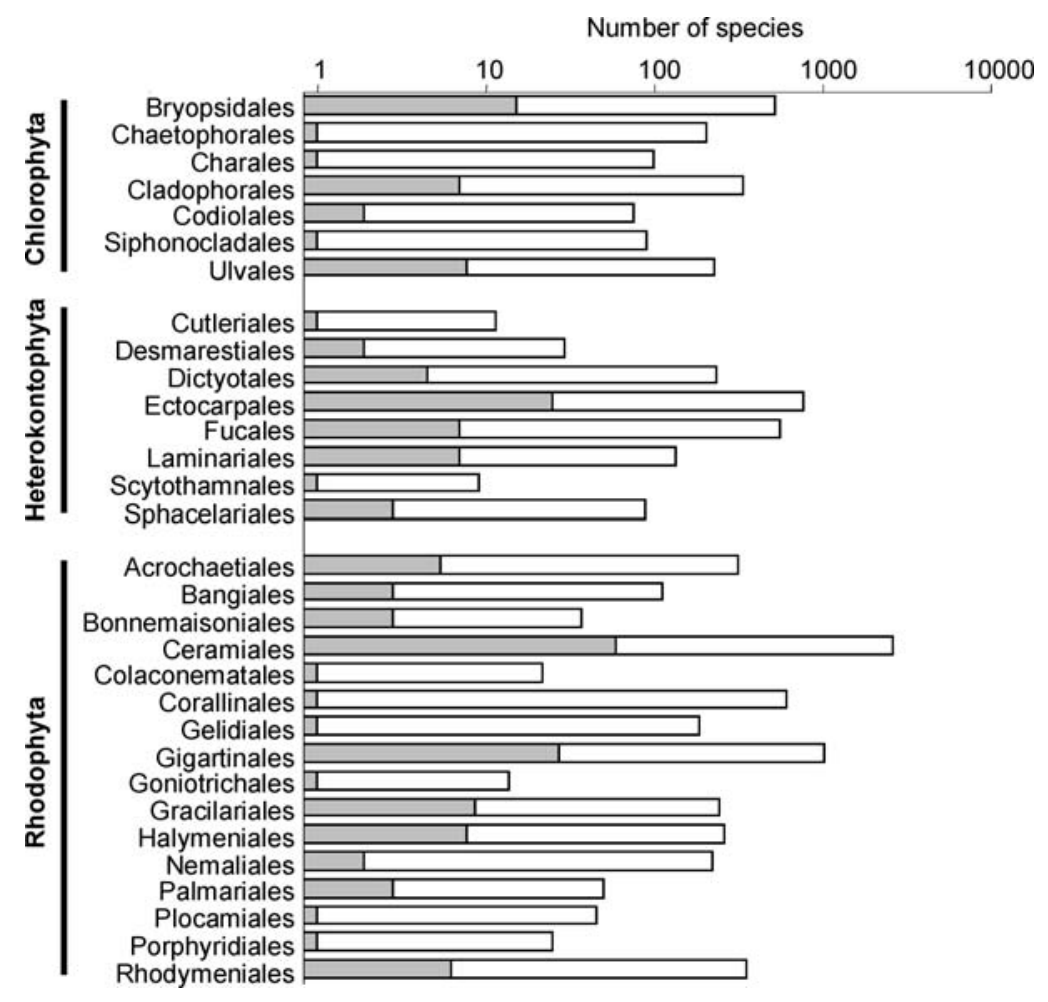

Figure 1. Proportion of number of introduced (grey bars) to total number of species (white bars) in macroalgal orders containing introduced species. Note logarithmic scale. Data are from a database with published records of introduced macroalgae (Smith et al., unpublished data) and AlgaeBase (http://www.algaebase.org, (c)1996 - 2004 M.D. Guiry).

important vector for macroalgal introductions (Lewis, 1999; Hewitt et al., 2004). Availability of large numbers of propagules would facilitate colonisation of ships' hulls and other surfaces. For example, high-density populations of $U$. pinnatifida and Laminaria japonica J. E. Areschoug occur along the North West Pacific coasts, where the two species are widely cultivated. In these areas the probability is high for zoospores or gametophytes to settle on ships' hulls, aquaculture stock (e.g. oysters) and equipment. Introduced Codium fragile ssp. tomentosoides in Australia is also generally found in modified environments, often associated with shipping-related infrastructure such as marinas, wharfs, jetties, rip rap, and mooring sites.

In historical times, wooden ships carried vast amounts of fouling species, including macroalgae, on hulls and ballast rock (Carlton \& Hodder, 1995; Carlton, 2003). This may explain the cosmopolitan distribution of many well-known fouling taxa such as members of the Ceramiaceae, Ectocarpaceae, Ulvaceae and Cladophoraceae. These are now considered to be 'cryptogenic' (of unknown origin, sensu Carlton, 1996a) in many locations, and include species that may have been introduced many centuries ago. The use of antifouling paint on modern vessels provides only partial protection. Even large vessels have areas on the hull and internal water intake structures (sea chests) that are not or incompletely antifouled and can be colonised by fouling species (Coutts et al., 2003). Smaller vessels, such as small commercial boats, private yachts and launches commonly used in coastal marine traffic may pose an even higher risk due to (i) their usual residence in coastal waters close to seaweed habitats, (ii) their frequently extensive mooring periods, (iii) their slow travel speed, and (iv) their highly variable hull maintenance patterns (Floerl \& Inglis, in press; Floerl et al., in press). The incidence of hull fouling is likely to increase as the use of tributyltin (TBT), the main active ingredient in antifouling paints for commercial vessels, will be globally phased out by 2008 for environmental reasons (International Convention on the Control of Harmful Antifouling Systems on Ships 20012). ${ }^{1}$

\footnotetext{
${ }^{1}$ Adopted 5 October 2001, http://www.imo.org accessed 18 May
} 
Ballast water is the most important pathway for the introduction of plankton, species with planktonic life history stages and fish (Minchin \& Gollasch, 2002). Ballast water is suggested as an important vector for $U$. pinnatifida, possibly transporting zoospores or suspended gametophytes (Hay \& Luckens, 1987; Hay, 1990). However, an extensive international study of the species composition in ballast water tanks found only fragments of four macroalgal taxa within a total of 990 taxa (bacteria, fungi, protozoans, algae, invertebrates and fishes; Gollasch et al., 2002). We consider ballast water to be a less important pathway for macroalgal introductions. However, macroalgae may occur in the much less studied sediments deposited in ballast tanks.

The direct introduction of seaweed species for aquaculture is an important vector, especially in tropical regions (Smith et al., 2002). Eucheuma and Kappaphycus species have been introduced for production of carrageenan to 26 countries in the Pacific, east Africa and the Caribbean (Zemke-White, in press). Another well-known example is the translocation of introduced $U$. pinnatifida for aquaculture from the Mediterranean to Brittany where it established in the natural environment and spread along the Atlantic coast (reviewed in Wallentinus, 1999b).

The transport and cultivation of NIMS in the domestic and international aquarium trade, including public, private and research aquarium facilities, are potential pathways for the introduction of macroalgae. Whole thalli, fragments or propagules can be released to waterways through untreated effluent or disposal of biomass. The best-known example is the introduction of Caulerpa taxifolia into the Mediterranean, presumably by accidental release from a public aquarium (Meinesz \& Boudouresque, 1996). Eleven species of marine macroalgae are available through the aquarium trade (Wallentinus 2002), as well as 'live rock', natural substratum cultivated for its variety of attached epibionts including macroalgae (Wallentinus, 2002; Frisch \& Murray, 2002).

Macroalgal introductions to Europe are dominated by associations with aquaculture vectors (Maggs \& Stegenga, 1999; Reise et al., 1999; Ribera Siguan, 2002; Wallentinus, 2002). The large-scale import of the Pacific Oyster to Europe in the 20th century, typically without any quarantine measures (Wolff \& Reise, 2002), may explain the high proportion of Pacific macroalgae in European waters (data in Wallentinus, 2002).
Transport from the Red Sea through the Suez Canal into the Mediterranean ('Lessepsian migrations') was the most important vector for the introduction of macroalgae into the Mediterranean until the early 1990s (Ribera Siguan, 2003). Release of seaweed used for wrapping of fishing bait or seafood is a vector of local importance (Ribera Siguan, 2002; 2003; Wallentinus, 2002).

After uptake by the vector the species must survive the journey to a new location. To our knowledge, there have been no experimental studies on the trans-oceanic survival of hull-fouling species (but see Carlton \& Hodder, 1995). We assume, however, species would survive if thalli are not physically dislocated and if the temperature and salinity regimes encountered during the journey were within their physiological tolerances (e.g., Hayes \& Hewitt, 2000; Hewitt \& Hayes, 2002). Physiological tolerance data are available for a large number of macroalgae. For example, $U$. pinnatifida gametophytes survive temperatures of -1 to $30^{\circ} \mathrm{C}$ and salinities of above 15 ppt (Saito, 1975). Caulerpa taxifolia and Codium fragile ssp. tomentosoides survive emersion in high humidity for up to 10 and 90 days, respectively, potentially enabling them to survive shipboard transport for extended periods, for example entangled in fishing nets (Sant et al., 1996; Schaffelke $\&$ Deane, in press).

\section{Release and establishment}

Following release, a successful invader must survive and establish itself in the receiving environment. This phase in the invasion process is least well known for seaweeds. The definition of establishment has been ambiguous in the literature (Hewitt et al., unpublished). Here we use the definition of established as forming 'a reproductive and self-sustaining population' (e.g., Case, 1996; Williamson \& Fitter, 1996; Duncan et al., 2001).

Establishment success is mainly determined by a combination of the following three factors:

- Inoculum pressure (vector frequency and rate of vector infection);

- Abiotic and biological characteristics of the receiving environment; and

- Eco-physiological characteristics of the arriving species.

Embayments and estuaries appear to more prone to introductions than open coast habitats (Carlton, 1996b). These environments, however, also have high 
inoculum pressure, i.e. one or more significant vectors are generally present in port environments and urbanised embayments (Ruiz et al., 2000). International ports and harbours are both primary points of inoculation and initial establishment but may also be source populations for secondary spread (e.g., Ruiz et al., 2000; Hewitt, 2002; Ruiz \& Hewitt, 2002; Hewitt et al., 2004). The accidental release of aquarium species is also significantly correlated with urban centers. Similarly, aquaculture facilities are typically located in embayments, often immediately adjacent to port environments. These locations represent 'hot spots' of species introduction (Ruiz \& Hewitt, 2002; Hewitt, 2003a), even though invasions do occur in a wide variety of marine habitats (Carlton, 2002).

Successful establishment of species after arrival is dependent on matching environmental conditions in the source and recipient environments (e.g., Hewitt \& Hayes, 2002). For example, low winter temperatures seem to have prevented the establishment of Porphyra yezoensis Ueda, introduced for aquaculture to the east coast of the United States (Watson et al., 2000) and of Caulerpa taxifolia in Japan, where it escaped from an aquarium facility (Komatsu et al., 2003). Risk assessments for bioinvasions use environmental conditions to predict, for example, whether the ballast water taken up by a vessel is of high risk to the environment at the destination, and species-specific physiological tolerance data to identify the risk of inoculation of a specific site (Hewitt \& Hayes, 2002).

Some recipient environment characteristics are associated with increased introduction incidence: low native biodiversity and anthropogenic disturbance (e.g., water and sediment pollution, structures providing artificial substrates and altered temperature regime due to effluents; reviewed in Carlton, 1996b and Gollasch \& Leppäkoski, 1999). For example, the establishment of $U$. pinnatifida in Australia was facilitated by reduced native macroalgal cover (Valentine \& Johnson, 2003; 2004). Habitat 'invasibility' is also dependent on functional diversity of macroalgal habitats, e.g. less diverse algal turf assemblages and seagrass meadows can promote the establishment of introduced Caulerpa species (Cecherelli \& Cinelli, 1998; Ceccherelli et al., 2002). C. taxifolia establishment and proliferation has been linked to enrichment of substrata by urban wastewater and organic matter (Chisholm et al., 1997). Extensive blooms of non-indigenous C. brachypus Harvey, recently discovered in Florida, may also be linked to local nutrient enrichment (Jacoby et al., 2004).
There is evidence that changes caused by numerous introductions into one region can synergistically operate as a biological disturbance agent and pave the way for new introductions, which has been called "invasional meltdown" (Simberloff \& von Holle, 1999).

The successful establishment of Codium fragile ssp. tomentosoides in the North West Atlantic (Nova Scotia, Canada) versus presence at only low abundances in the North East Atlantic (England) has been explained by biological differences of the native community, despite similar abiotic environmental characteristics (Chapman, 1999). In the northeast Atlantic benthic biodiversity and grazing rates are high, whereas in the northwest Atlantic periodic disturbance of native kelp beds by sea urchin grazing has opened a window suitable for $C$. fragile ssp. tomentosoides establishment. This has been facilitated by factors that disrupt the natural sea urchin/kelp dynamics: spreading of the introduced bryozoan Membranipora membranacea that overgrows kelp blades and of several introduced red seaweeds colonising vacant space created by urchin grazing (Levin et al., 2002). In addition, grazing pressure is reduced by the decimation of the sea urchin Strongylocentrus droebachiensis from an amoebic disease, which presumably is also introduced (Harris \& Tyrell, 2001; Chapman et al., 2002), and by avoidance of $C$. fragile ssp. tomentosoides by grazers (Scheibling \& Anthony, 2001).

Species traits may facilitate the establishment of NIMS. Applying the properties of successful invaders after Lodge (1993), several $r$-selected traits have been identified for Codium fragile ssp. Tomentosoides, such as high growth rate and reproductive output, vegetative and parthenogenetic reproduction, and broad environmental tolerances (Chapman, 1999). However, most of these characteristics also apply to non-invasive subspecies of $C$. fragile (Trowbridge, 1998). In contrast, a quantitative ranking of European introduced and native seaweed species (using categories of species traits such as dispersal capabilities, environmental tolerances, reproductive mode, and size) indicated that introduced species indeed have species traits that increase the likelihood of successful invasion (Nyberg \& Wallentinus, in press). Species most likely to be successful are: $C$. fragile ssp. tomentosoides, Caulerpa taxifolia, U. pinnatifida, Asparagopsis armata Harvey and Grateloupia doryphora (the currently accepted name for this species is G. turuturu Yamada (Gavio \& Fredericq, 2002), however, the identity of records from Sicily has recently been disputed (Wilkes et al., unpublished data)). 


\section{Spread and impact}

From the initial incursion sites, for example close to international ports or aquaculture facilities, NIMS spread to other areas by natural dispersal or by domestic translocation. Vectors for domestic translocation are similar to those of the initial introduction, such as aquaculture stock movements, coastal and recreational shipping (Kinloch et al., 2003).

Caulerpa taxifolia in the Mediterranean has spread steadily since its introduction in 1984, with an estimated colonised area of $131 \mathrm{~km}^{2}$ (Meinesz et al., 2001). However, the current distribution and local abundance is disputed and remote sensing results suggest that $C$. taxifolia cover along the south coast of France may have been overestimated by a factor of ten (Jaubert et al., 2003). Since the early 1990s a second Caulerpa species has been spreading in the Mediterranean Sea, now identified as the proposed combination C. racemosa var. cylindracea (Sonder) Verlaque, Huisman et Boudouresque (Verlaque et al., 2003). The rate of spread of $C$. racemosa var. cylindracea and the co-occuring Womersleyella setacea (Hollenberg) R. Norris (see below) is dramatic compared to other introduced macroalgae in Europe (Verlaque et al., 2004). C. racemosa var. cylindracea is competitively superior to $C$. taxifolia, where the two species co-occur (Piazzi et al., 2001a; Piazzi \& Ceccherelli, 2002).

The understanding of one introduction often cannot predict other introductions of the same species, as the factors determining success of establishment and further spread are site- or time-specific (Grosholz, 1996; see above for Codium fragile ssp. tomentosoides). While Boudouresque and Verlaque (2002) do not consider $U$. pinnatifida as an invasive species in the Mediterranean Sea (defined as NIMS that spread from the point of introduction and become abundant; Kolar and Lodge, 2001) the species is invasive, indicated by the continuously expanding range, along the European Atlantic coast (Wallentinus, 1999b), the west coast of the United States and Mexico (Silva et al., 2002; L. Aguilar Rosas, pers. comm.) and in the southern hemisphere (Sinner et al., 2000; Casas et al., in press).

Studies of impacts of NIMS are often hampered by the lack of ecological baseline studies. Typically, studies are only initiated after the incursion has already occurred and use comparisons of sites colonised and un-colonised by NIMS (Hewitt, 2003b). In such a study on U. pinnatifida Forrest and Taylor (2002) found no differences in native species richness and abundance, but suggest that the lack of benthic community data be- fore establishment of $U$. pinnatifida limits inferences. $U$. pinnatifida has caused changes to the composition of native macroalgal communities (Battershill et al., 1999; Sinner et al., 2000, Valentine and Johnson, 2003), as well as decreases in cover (Curiel et al. 1998, 2001) and diversity (Casas et al., in press). Short-term studies indicated that the presence of Caulerpa taxifolia had a negative effect on seagrass shoot density, especially under nutrient enrichment (Ceccherelli and Cinelli, 1997). In contrast, long-term experiments suggest that C. taxifolia and seagrass are likely to co-exist and that high nutrient availability will not change competitive relations (Ceccherelli and Sechi, 2002). Overgrowth by C. racemosa changed macroalgal community composition and seagrass shoot density (Piazzi et al., 2001b; Ceccherelli and Campo, 2002).

Impacts of NIMS may also change through time. NIMS often persist at low levels and later start to increase in abundance and spread, which Stockwell et al. (2003) attributes to either an initial period of adaptation or a change to previously functional environmental controls such as competition or grazing. In contrast, adaptations to NIMS may also occur by herbivores changing preferences from native species to NIMS (Stimson et al., 2001). In other cases NIMS are not preferred (Schaffelke et al., 1995), preferred by only a few grazers (Trowbridge, 1998; Thornber et al., 2004) or no change of grazer populations and feeding habits was observed (Francour et al., 1995).

Apart from the handful of high profile species, rhodophytes are the most prevalent group of introduced macroalgae (Ribera Siguan, 2003). It is likely that consequences of these introductions are underestimated because the taxa involved are often inconspicuous and difficult to identify to species level. This is further complicated by separate introductions of morphologically dissimilar generations (e.g. gametophytes vs. tetrasoporophytes of Asparagopsis armata, Maggs and Stegenga, 1999) or cryptic invasions of sibling species that are morphologically indistinguishable from native species (e.g. McIvor et al., 2001). The detection of cryptic invasions is much aided by molecular techniques, which can also assist in the assignment of source regions of introductions (see below).

At least 21 seaweed species have been introduced to the Hawaiian Islands, both accidentally and intentionally for seaweed aquaculture (Godwin, 2001; Smith et al., 2002). The islands represent one of the most heavily invaded tropical systems in the world. Several species (Acanthophora spicifera (M. Vahl) Børgesen, Avrainvillea amadelpha (Montagne) A. Gepp and E.S. 
Gepp, Gracilaria salicornia (C. Agardh) E.Y. Dawson, Hypnea musciformis (Wulfen) J.V. Lamouroux, Kappaphycus spp. and Eucheuma spp.), predominantly Rhodophytes, are now established in high abundance and spreading (Smith et al., 2002; Conklin and Smith, in press; G. Zucarello, pers. comm.). Four of these species are overgrowing live hard corals, sometimes leading to coral mortality (Smith et al., 2002). Costs associated with $H$. musciformis blooms are $\sim$ US $\$ 55,000$ per year for one town alone, for removal of rotting algal biomass washed up onto beaches (Van Beukering and Cesdar, 2004).

Womersleyella setacea is an Indo-Pacific species (e.g. Silva et al., 1996), recently introduced into the Mediterranean Sea (first report in Verlaque, 1989) where it is now widely distributed (Airoldi et al., 1995; Piazzi and Cinelli, 2001), and is also found in the Canary Islands (Haroun et al., 2002). The species has developed dense turf assemblages on rocky substratum and on seagrass rhizomes, with reduced biodiversity compared with unaffected sites (Piazzi et al., 2002; Piazzi and Cinelli, 2003).

Heterosiphonia japonica Yendo, a North Pacific species (e.g., Abbott and Hollenberg, 1976; Yoshida et al., 1990), was recently introduced to the East Atlantic and Mediterranean Sea, potentially by oyster imports, and has since spread along the Atlantic coasts of Spain, France, and Norway (Lein, 1999; Maggs and Stegenga, 1999; Verlaque, 2001). It is now the most common species in sheltered and semi-exposed subtidal locations along the south-west coast of Norway, overgrowing other benthos (Husa et al., 2004). Further north $H$. japonica is found mainly in or near harbours, indicating translocation by shipping and fishing activities (Husa et al., 2004).

\section{Management options}

Several steps have been identified as fundamental to the management of NIMS: prevention and monitoring; detection and rapid response; and long-term control. The development of awareness and understanding by public and political interests, appropriate research strategies, and information management and sharing, underpin these steps.

\section{Prevention and monitoring}

The most cost-effective management strategy in the marine environment will be to reduce the introduction risks through minimisation of inoculation frequency and propagule pressure. These options cannot be solely driven at a local or national level, but require significant international and regional cooperation (e.g., Bax et al., 2003; Hewitt, 2003a). Several international and multilateral regional actions have recently been enacted to reduce the rates of NIMS transfers from various vectors. Examples include: The International Convention for the Control and Management of Ship's Ballast Water and Sediments (http://www.imo.org; see also Hewitt, 2003a; McConnell, 2003) that now requires ratification. This convention will create a uniform standard for the regulation of ballast water management. The International Council for the Exploration of the Seas (ICES) developed a Code of Practice (CoP) for the Introductions and Transfers of Marine Organisms in 1994 (updated in 2003, available at http://www.ices.dk). This CoP aids the management of intentional introductions (e.g., mariculture and stocking) and accidental introductions associated with aquaculture species. However, most effective would be a preferential development of aquaculture of native species. APEC has undertaken an assessment of regulatory frameworks for NIMS management in member economies (Bax et al., 2003) to develop a common regional risk management framework for NIMS, primarily targeting ballast water and hull fouling. Altogether, these actions do not fully address the dominant pathways for macroalgal introductions, i.e., translocations for aquaculture and fouling of marine vessels and installations.

\section{Detection, rapid response and long-term control}

Most management plans for introduced species have elements of 'rapid response' for eradication action, identifying when and how to shift to long-term control (e.g., Wotton and Hewitt, 2004). Rapid response requires early detection, either through passive (e.g., public reporting) or active means (e.g., surveillance program) and an understanding of what is already present (e.g., baseline surveys). Australia and New Zealand have the established national systems of port baseline surveys using standardised collection methods (Hewitt and Martin, 2001; Ruiz and Hewitt, 2002).

The determination of source regions is fundamental to decisions on management action after discovery of an introduction. For example, Caulerpa taxifolia was discovered between 2000 and 2002 in both the USA (California) and in Australia (New South Wales 
and South Australia). There are no native Caulerpa species in California, making the determination as an introduced species unequivocal. The two populations were identified as genetically identical with the 'aquarium-Mediterranean strain' (Jousson et al., 2000). A campaign to eradicate the alga commenced in the same year. In Australia, however, C. taxifolia is native to the tropical and subtropical regions (reviewed in Phillips and Price, 2002). Several populations of $C$. taxifolia were discovered in the region around Sydney, more than $800 \mathrm{~km}$ south of previous records, and even further away around Adelaide. Using molecular markers, Schaffelke et al. (2002) and Murphy and Schaffelke (2003) ruled out that $C$. taxifolia was introduced from overseas, i.e. from the Mediterranean or overseas aquaria, with high confidence for three of six new locations. It is most likely that the new records are the result of domestic translocation(s) from Australian (sub)tropical populations, assisted by human activities such as boat traffic and fishing or through the domestic aquarium trade (Schaffelke et al., 2002). A number of molecular markers are identical between the 'aquarium-Mediterranean strain' and certain Australian populations, indicating that the latter may be the origin of the introduction into the international aquarium market and thence to the Mediterranean (Meusnier et al., 2002, 2004; Fama et al., 2002). Recent molecular research indicates that $C$. taxifolia consists of at least two incipient species, of which only one is known to be invasive, and that there is evidence for a second, previously unrecognised, introduction event into the Mediterranean Sea (Meusnier et al., 2002, 2004).

Rapid response activities entail a variety of methods (e.g., physical or chemical control) with the intent of containing and eradicating introduced species as soon after detection as possible. Benefits and hazards of eradication/control efforts need to be balanced against the benefits and hazards of doing nothing, specific to each species and location (Hewitt et al., in press). While physical removal/control of introduced macroalgae (especially Caulerpa taxifolia) has shown some promising results, other methods such as chemical and biological control had limited effect (reviewed in McEnnulty et al., 2001). Recent efforts to eradicate or control $C$. taxifolia using chemical methods are more encouraging. In Australia, application of sea salt at 50 $\mathrm{kg} \mathrm{m}^{-2}$ was successful in reducing abundance of the target species by up to $95 \%$ whereas native seagrass and infauna were less affected and had largely recov- ered after 6 months (Glasby et al., unpub data). In California, chlorine was applied under black tarpaulins left in place for several months, after which no C. taxifolia was found in cores from the treated area (Anderson, 2002). Laboratory tests indicate that chlorine concentrations of $125 \mathrm{ppm}$ for at least $30 \mathrm{~min}$ result in $100 \%$ mortality, and that treatment should preferably occur in winter when $C$. taxifolia grows slowly (Williams and Schroeder, 2004).

Manual removal of $U$. pinnatifida significantly reduces sporophyte numbers. However, in established populations, survival over more than 2.5 years occurs either through 'seed banks' of microscopic stages or selective gametophyte survival in microhabitats (Hewitt et al. in press). Zoospore release in $U$. pinnatifida in Australia is limited to larger sporophytes for most of the growing season, but late in the season small sporophytes form mature sporophylls within just one month (Schaffelke et al., in press). Hence, removal efforts need to be more frequent in the late season. Removal of Kappaphycus spp. in Hawai'i required $\sim 2 \mathrm{~h} \mathrm{~m}^{-2}$ and regrowth was rapid (Conklin and Smith, in press). Manual removal of introduced macroalgae is a longterm commitment, and needs to be coupled with vector management and education to reduce the chances of re-inoculation and spread, and with monitoring (and response) on a larger spatial scale for the early detection of new incursion sites.

The eradication, or even control, of marine invasive species is both technically difficult and costly (Meyerson \& Reaser, 2002). Globally, few marine incursions have resulted in response actions and, of those, a limited number have succeeded (e.g., Bax, 1999; Culver \& Kuris, 2000; Wotton et al., in press). The recent successful eradication of $U$. pinnatifida, from the Chatham Islands near New Zealand was achievable because it only occurred on a single sunken vessel hull on sandy substrate, limiting the likelihood of spread (Wotton et al., in press). The total cost of this eradication was in excess of $\sim$ US $\$ 1.8$ million (ibid.). The costs of the eradication campaign for $C$. taxifolia in California are to date $\sim$ US $\$ 4$ million (R. Woodfield, pers. comm.).

Lastly, the crux to any long-term control or eradication effort will be sustained public and political will. Biosecurity must identify impacts of introductions in economic and social terms, create gains that can be readily identified, but also communicate losses and identify the causes, and link biosecurity to tangible examples that remain of current interest. 


\section{Conclusion}

Macroalgal introductions are increasing. Despite sometimes being a new resource for harvest and aquaculture, there is a growing understanding of the often significant ecological and economic impacts of these introductions. Only sustained biosecurity management, based on better knowledge of invasion ecology, will prevent these impacts from changing ecosystems as we know them.

\section{Acknowledgements}

We thank Mike Guiry for the provision of species numbers from AlgaeBase and Keith Hayes for information from the CSIRO NIMPIS database. We also thank the colleagues who made unpublished information available to us.

\section{References}

Abbott IA, Hollenberg GJ (1976) Marine Algae of California. Stanford University Press, Stanford, USA.

Airoldi L, Rindi F, Cinelli F (1995) Structure, seasonal dynamics and reproductive phenology of a filamentous turf assemblage on a sediment influenced, rocky subtidal shore. Bot. Mar. 38: 227237.

Anderson LWJ (2002) Caulerpa taxifolia in the United States: rapid response and eradication program. International Caulerpa taxifolia Conference Proceedings, January 31-February 1, 2002. California Sea Grant College Program, La Jolla. Publication No. T-047 (CD-ROM).

Battershill C, Miller K, Cole R (1999) The understorey of marine invasions. Seafood NZ 6: 31-33.

Bax NJ (1999) Eradicating a dreissenid from Australia. Dreissena! 10: $1-5$.

Bax N, Williamson A, Aguero M, Gonzalez E, Geeves W (2003) Marine invasive species: A threat to global biodiversity. Mar. Policy 27: 313-323.

Boudouresque CF, Verlaque M (2002) Biological pollution in the Mediterranean Sea: Invasive versus introduced macrophytes. Mar. Poll. Bull. 44: 32-38.

Carlton JT (1996a) Biological invasions and cryptogenic species. Ecology 77: 1653-1655.

Carlton JT (1996b) Pattern, process, and prediction in marine invasion ecology. Biol. Cons. 78: 97-106.

Carlton JT (2000) Global change and biological invasions in the Oceans. In Mooney HA, Hobbs RJ (eds), Invasive Species in a Changing World, Island Press, Washington DC, pp. 31-53.

Carlton JT (2001) Introduced species in U. S. coastal waters: Environmental impacts and management priorities. Pew Oceans Commission, Arlington, Virginia. 28 pp.

Carlton JT (2002) Bioinvasion ecology: Assessing invasion impact and scale. In Leppäkoski E, Gollasch S, Olenin S (eds), Invasive
Aquatic Species of Europe. Distribution, Impacts and Management, Kluwer Academic Publishers, Dordrecht, pp. 7-19.

Carlton JT (2003) Community assembly and historical biogeography in the North Atlantic Ocean: The potential role of humanmediated dispersal vectors. Hydrobiologia 503: 1-8.

Carlton JT, Hodder J (1995) Biogeography and dispersal of coastal marine organisms: Experimental studies on a replica of a 16thcentury sailing vessel. Mar. Biol. 121: 721-730.

Casas G, Scrosati R, Piriz ML, in press. The invasive kelp Undaria pinnatifida (Phaeophyceae, Laminariales) reduces native seaweed biodiversity in Nuevo Gulf (Patagonia, Argentina). Biological Invasions.

Case TJ (1996) Global patterns in the establishment and distribution of exotic birds. Biol. Cons. 78: 69-96.

Castilla JC, Uribe M, Bahamonde N, Clarke M, DesqueyrouxFaúndez R, Kong I, Moyano H, Rozbaczylo N, Santelices B, Valdovinos C, Zavala P, in press. Down under the southeastern Pacific: Marine non-indigenous species in Chile. Biological Invasions.

Ceccherelli G, Campo D (2002) Different effects of Caulerpa racemosa on two co-occurring seagrasses in the Mediterranean. Bot. Mar. 45: 71-76.

Ceccherelli G, Cinelli F (1997) Short-term effects of nutrient enrichment of the sediment and interactions between the seagrass $\mathrm{Cy}$ modocea nodosa and the introduced green alga Caulerpa taxifolia in a Mediterranean bay. J. Exp. Mar. Biol. Ecol. 217: 165-177.

Ceccherelli G, Cinelli F (1998) Habitat effect on spatio-temporal variability in size and density of the introduced alga Caulerpa taxifolia. Mar. Ecol. Prog. Ser. 163: 289-294.

Ceccherelli G, Sechi N (2002) Nutrient availability in the sediment and the reciprocal effects between the native seagrass Cymodocea nodosa and the introduced rhizophytic alga Caulerpa taxifolia. Hydrobiologia 474: 57-66.

Ceccherelli G, Piazzi L, Balata D (2002) Spread of introduced Caulerpa species in macroalgal habitats. J. Exp. Mar. Biol. Ecol. 280: 1-11.

Chapman AS (1999) From introduced species to invader: What determines variation in the success of Codium fragile ssp. tomentosoides (Chlorophyta) in the North Atlantic Ocean? Helgol. Meeresunters. 52: 277-289.

Chapman AS, Scheibling RE, Chapman ARO (2002) Species introductions and changes in the marine vegetation of Atlantic Canada. In Claudi R, Nantel P, Muckle-Jeffs E (eds), Alien Invaders in Canada's Waters, Wetlands and Forests, Natural Resources Canada, Canadian Forest Service, Science Branch, Ottawa, pp. 133-148.

Chisholm JRM, Fernex FE, Mathieu D, Jaubert JM (1997) Wastewater discharge, seagrass decline and algal proliferation on the Cote d'Azur. Mar. Poll. Bull. 34: 78-84.

Cohen AN, Carlton JT (1995) Non-indigenous aquatic species in a United States estuary: A case study of the biological invasions of the San Francisco Bay and Delta. Report to US Fish and Wildlife Service, Washington DC.

Coles SL, DeFelice LG, Carlton JT (1999) Historical and recent introductions of non-indigenous marine species into Pearl Harbour, Oahu, Hawaiian Islands. Mar. Biol. 135: 147-158.

Conklin EJ, Smith JE (2005) Abundance and spread of the invasive red alga, Kappaphycus spp., in Kane'ohe Bay, Hawai'i and an experimental assessment of management options. Biological Invasions 7: 1029-1039. 
Coutts ADM, Moore KM, Hewitt CL (2003) Ships' sea chests: An overlooked transfer mechanism for non-indigenous marine species? Mar. Poll. Bull. 46: 1504-1515.

Cranfield HJ, Gordon DP, Willan RC, Marshall BA, Battershill CN, Francis MP, Nelson WA, Glasby CJ, Read GB (1998) Adventive species in New Zealand., NIWA Technical Report \#34, Wellington, New Zealand.

Culver CS, Kuris AM (2000) The apparent eradication of a locally established introduced marine pest. Biological Invasions 2: 245-253.

Curiel D, Bellemo G, Marzocchi M, Scattolin M, Parisi G (1998) Distribution of introduced Japanese macroalgae Undaria pinnatifida, Sargassum muticum (Phaeophyta) and Antithamnion pectinatum (Rhodophyta) in the Lagoon of Venice. Hydrobiologia 385: 17-22

Curiel D, Guidetti P, Bellemo G, Scattolin M, Marzocchi M (2001) The introduced alga Undaria pinnatifida (Laminariales, Alariaceae) in the Lagoon of Venice. Hydrobiologia 477: 209-219.

Duncan RP, Bomford M, Forsyth DM, Conibear L (2001) High predictability in introduction outcomes and the geographical range size of introduced Australian birds: A role for climate. J. Anim. Ecol. 70: 621-632.

Fama P, Jousson O, Zaninetti L, Meinesz A, Dini F, Giuseppe GDi, Millar AJK, Pawlowski J (2002) Genetic polymorphism in Caulerpa taxifolia (Ulvophyceae) chloroplast DNA revealed by a PCR-based assay of the invasive Mediterranean strain. J. Evol. Biol. 15: 618-624.

Floerl O, Inglis GJ (2005) Starting the invasion pathway: The interaction between source populations and human transport vectors. Biological Invasions 7: 589-606.

Floerl O, Inglis GJ, Marsh HM (2005) Selectivity in vector management: An investigation of the effectiveness of measures used to prevent transport of non-indigenous species. Biological Invasions 7: 459-475.

Forrest BM, Taylor MD (2002) Assessing invasion impact: Survey design considerations and implications for management of an invasive marine plant. Biological Invasions 4: 375-386.

Francour P, Harmelin-Vivien M, Harmelin JG, Duclerc J (1995) Impacts of Caulerpa taxifolia colonization on the littoral ichtyofauna of North-Western Mediterranean sea: Preliminary results. Hydrobiologia 300/301: 345-353.

Frisch S, Murray S (2002) The availability of Caulerpa spp. and "Live Rock" in retail aquarium outlets in southern California. International Caulerpa taxfolia Conference Proceedings, January 31-February 1, 2002. California Sea Grant College Program, La Jolla. Publication No. T-047 (CD-ROM).

Gavio B, Fredericq S (2002) Grateloupia turuturu (Halymeniaceae, Rhodophyta) is the correct name of the non-native species in the Atlantic known as Grateloupia doryphora. Eur. J. Phycol. 37: 349-359.

Godwin LS (2001) Hull fouling of maritime vessels as a pathway for marine species invasions to the Hawaiian Islands. In Proceedings of the 24th Meeting of the Marine Facilities Panel of the United States Japan Cooperative Program in Natural Resources, November 4-10, 2001: 1-10.

Gollasch S, Leppäkoski E (1999) Initial risk assessment of alien species in Nordic coastal waters. Nord 1999: 8. Nordic Council of Ministers, Copenhagen.

Gollasch S, Macdonald E, Belson S, Botnen H, Christensen JT, Hamer JP, Houvenaghel G, Jelmert A, Lucas I, Masson D, McCollin T, Olenin S, Persson A, Wallentinus I, Wetsteyn LPMJ,
Wittling T (2002) Life in ballast tanks. In Leppäkoski E, Gollasch $\mathrm{S}$, Olenin S (eds), Invasive Aquatic Species of Europe. Distribution, Impacts and Management, Kluwer Academic Publishers, Dordrecht: pp. 217-231.

Goulletquer P, Bachelet G, Guy Sauriau P, Noel P (2002) Open Atlantic coast of Europe-a century of in troduced species into French waters. In Leppäkoski E, Gollasch S, Olenin S (eds), Invasive Aquatic Species of Europe. Distribution, Impacts and Management, Kluwer Academic Publishers, Dordrecht, pp. 276-290.

Grosholz ED (1996) Contrasting rates of spread for introduced species in terrestrial and marine systems. Ecology 77: 16801686.

Haroun RJ, Gil-Rodriguez MC, de Castro JD, van Reine WFP (2002) A checklist of the marine plants from the Canary Islands (Central Eastern Atlantic Ocean). Bot. Mar. 45: 139-169.

Harris LG, Tyrrell MC (2001) Changing community states in the Gulf of Maine: synergism between invaders, overfishing and climate change. Biological Invasions 3: 9-21.

Hay CH (1990) The dispersal of sporophytes of Undaria pinnatifida by coastal shipping in New Zealand, and implications for further dispersal of Undaria in France. Br. Phycol. J. 25: 301-313.

Hay CH, Luckens PA (1987) The Asian kelp Undaria pinnatifida (Phaeophyta: Laminariales) found in a New Zealand harbour. NZ J. Bot. 25: 329-332.

Hayes K, Hewitt CL (2000) Risk assessment framework for ballast water introductions - Volume II. Centre for Research on Introduced Marine Pests Technical Report No. 21, CSIRO Marine Research, Hobart.

Hewitt CL (2002) The distribution and diversity of tropical Australian marine bio-invasions. Pacific Science 56: 213-222.

Hewitt CL (2003a) Marine biosecurity issues in the world oceans: Global activities and Australian directions. Ocean Yearbook 17: 193-212.

Hewitt CL (2003b) The diversity of likely impacts of introduced marine species in Australian waters. Records of the South Australian Museum Monographs Series 7: 3-10.

Hewitt CL, Hayes KR (2002) Risk assessment of marine biological invasions. In Leppäkoski E, Gollasch S, Olenin S (eds), Invasive Aquatic Species of Europe. Distribution, Impacts and Management, Kluwer Academic Publishers, Dordrecht: pp. 456-466.

Hewitt CL, Martin RB (2001) Revised protocols for baseline port surveys for introduced marine species - design considerations, sampling protocols and taxonomic sufficiency. Centre for Research on Introduced Marine Pests Technical Report No. 22. CSIRO Marine Research, Hobart.

Hewitt CL, Campbell ML, Thresher RE, Martin RB, Boyd S, Cohen BF, Currie DR, Gomon MF, Keough MJ, Lewis JA, Lockett MM, Mays N, McArthur MA, O'Hara TD, Poore GCB, Ross DJ, Storey MJ, Watson JE, Wilson RS (2004) Introduced and cryptogenic species in Port Phillip Bay, Victoria, Australia. Mar. Biol. 144: 183-202.

Hewitt CL, Campbell ML, McEnnulty F, Moore KM, Murfet NB, Robertson B, Schaffelke B (2005) Efficacy of physical removal of a marine pest: The introduced kelp Undaria pinnatifida in a Tasmanian Marine Reserve. Biological Invasions 7: 251-263.

Husa V, Sjøtun K, Lein TE (2004) The newly introduced species Heterosiphonia japonica Yendo (Dasyaceae, Rhodophyta): Geographical distribution and abundance at the Norwegian southwest coast. Sarsia 89: 211-217.

Jacoby C, Lapointe BE, Creswell L (2004) Are native and nonindigenous seaweeds overgrowing Florida's east coast reefs? 
Florida Sea Grant College Program. SGEF-156. Available at: http://flseagrant.org/program_areas/coastal_habitats/publications /SGEF_156_web.pdf [15/09/2004].

Jaubert JM, Chisholm JRM, Minghelli-Roman A, Marchioretti M, Morrow JH, Ripley HT (2003) Re-evaluation of the extent of Caulerpa taxifolia development in the northern Mediterranean using airborne spectrographic sensing. Mar. Ecol. Prog. Ser. 263: $75-82$.

Jousson O, Pawlowski J, Zaninetti L, Zechman FW, Dini F, Di Guiseppe G, Woodfield R, Millar A, Meinesz A (2000) Invasive alga reaches California. Nature 408: 157-158.

Kideys AE (2002) The comb jelly Mnemiopsis leidyi in the Black Sea. In Leppäkoski E, Gollasch S, Olenin S (eds), Invasive Aquatic Species of Europe. Distribution, Impacts and Management, Kluwer Academic Publishers, Dordrecht: pp. 56-61.

Kinloch M, Summerson R, Curran D (2003) Domestic vessel movements and the spread of marine pests. Department of Agriculture, Fisheries and Forestry, Commonwealth of Australia, Canberra.

Kolar CS, Lodge DM (2001) Progress in invasion biology: Predicting invaders. Trends Ecol. Evol. 16: 199-204.

Komatsu T, Ishikawa T, Yamaguchi N, Hori Y, Ohba H (2003) But next time? Unsuccessful establishment of the Mediterranean strain of the green seaweed Caulerpa taxifolia in the Sea of Japan. Biological Invasions 5: 275-277.

Lein TE (1999) A newly immigrated red alga ('Dasysiphonia', Dasyaceae, Rhodophyta) to the Norwegian coast. Sarsia 84: 85-88.

Levin PS, Coyer JA, Petrik R, Good TP (2002) Community-wide effects of nonindigenous species on temperate rocky reefs. Ecology 83: 3182-3193.

Lewis JA (1999) A review of the occurrence of exotic macroalgae in Southern Australia, with emphasis on Port Phillip Bay, Victoria. In Hewitt, CL, ML Campbell, RE Tresher \& RB Martin (eds), Marine Biological Invasions of Port Phillip Bay, Victoria. Centre for Research on Introduced Marine Pests Technical report No. 20. CSIRO Marine Research, Hobart: pp. 61-87.

Lodge DM (1993) Biological invasions: Lessons for ecology. Trends Ecol. Evol. 8: 133-137.

Maggs CA, Stegenga H (1999) Red algal exotics on the North Sea coasts. Helgol. Meeresunters. 52: 243-258.

McConnell ML (2003) Ballast and biosecurity: the legal, economic and safety implications of the developing international regime to prevent the spread of harmful aquatic organisms and pathogens in ship's ballast water. Ocean Yearbook 17: 213-255.

McEnnulty F, Bax NJ, Schaffelke B, Campbell ML (2001) A review of rapid response options for the control of ABWMAC listed introduced species and related taxa in Australian waters. Centre for Research on Introduced Marine Pests Technical Report No. 23. CSIRO Marine Research, Hobart.

McIvor L, Maggs CA, Provan J, Stanhope MJ (2001) RbcL sequences reveal multiple cryptic introductions of the Japanese red alga Polysiphonia harveyi. Mol. Ecol. 10: 911-919.

McKinney ML, Lockwood JL (1999) Biotic homogenization: A few winners replacing many losers in the next mass extinction. Trends Ecol. Evol. 14: 450-453.

Meinesz A, Boudouresque CF (1996) On the origin of Caulerpa taxifolia in the Mediterranean Sea. Science et Vie 319: 603-613.

Meinesz A, Belsher T, Thibaut T, Antolic B, Ben Mustapha K, Boudouresque CF, Chiaverini D, Cinelli F, Cottalorda J-M, Djellouli A, Abed A El, Orestano C, Grau AMM, Ivesa L, Jaklin A, Langar H, Massuti-Pascual E, Peirano A, Tunesi L, de Vaugelas J, Zavodnik N, Zuljevic A (2001) The introduced green alga
Caulerpa taxifolia continues to spread in the Mediterranean. Biological Invasions 3: 201-210.

Meusnier I, Valero M, Destombe C, Gode C, Desmarais E, Bonhomme F, Stam WT, Olsen JL (2002) Polymerase chain reactionsingle strand conformation polymorphism analyses of nuclear and chloroplast DNA provide evidence for recombination, multiple introductions and nascent speciation in the Caulerpa taxifolia complex. Mol. Ecol. 11: 2317-2325.

Meusnier I, Valero M, Olsen JL, Stam WT (2004) Analysis of rDNA ITS1 indels in Caulerpa taxifolia (Chlorophyta) supports a derived, incipient species status for the invasive strain. Eur. J. Phycol. 39: 83-92.

Meyerson LA, Reaser JK (2002) Biosecurity: Moving toward a comprehensive approach. BioScience 52: 593-600.

Minchin D, Gollasch S (2002) Vectors- how exotics get around. In Leppäkoski E, Gollasch S, Olenin S (eds), Invasive Aquatic Species of Europe. Distribution, Impacts and Management Kluwer Academic Publishers, Dordrecht, pp. 183-192.

Murphy NE, Schaffelke B (2003) Use of amplified fragment length polymorphism (AFLP) as a new tool to explore the invasive green alga Caulerpa taxifolia in Australia. Mar. Ecol. Prog. Ser. 246: 307-310.

Nichols FH, Thompson JK, Schemel LE (1994) Remarkable invasion of San Francisco Bay (California, USA) by the Asian clam Potamocorbula amurensis. II. Displacement of a former community. Mar. Ecol. Prog. Ser. 66: 95-101.

Norse EA (1993) Global Marine Biological Diversity. A Strategy for Building Conservation into Decision Making, Island Press, Washington DC.

Nyberg CD, Wallentinus I (2005) Can species traits be used to predict marine macroalgal introductions? Biological Invasions 7: 265-279.

Occhipinti Ambrogi A (2002) Current status of aquatic introductions in Italy. In Leppäkoski E, Gollasch S, Olenin S (eds), Invasive Aquatic Species of Europe. Distribution, Impacts and Management, Kluwer Academic Publishers, Dordrecht, pp. 311-324.

Occhipinti Ambrogi A, Savini D (2003) Biological invasions as a component of global change in stressed marine ecosystems. Mar. Poll. Bull. 46: 542-551.

Olden JD, Poff NL (2004) Clarifying biotic homogenization. Trends Ecol. Evol. 19: 282-283.

Olden JD, Poff NL, Douglas MR, Douglas ME, Fausch KD (2004) Ecological and evolutionary consequences of biotic homogenization. Trends Ecol. Evol. 19: 18-24.

Phillips JA, Price IR (2002) How different is Mediterranean Caulerpa taxifolia (Caulerpales: Chlorophyta) to other populations of the species? Mar. Ecol. Prog. Ser. 238: 61-71.

Piazzi L, Ceccherelli G (2002) Effects of competition between two introduced Caulerpa. Mar. Ecol. Prog. Ser. 225: 189-195.

Piazzi L, Cinelli F (2001) Distribution and dominance of two introduced turf-forming macroalgae on the oast of Tuscany, Italy, northwestern Mediterranean Sea in relation to different habitats and sedimentation. Bot. Mar. 44: 509-520.

Piazzi L, Cinelli F (2003) Evaluation of benthic macroalgal invasion in a harbour area of the western Mediterranean Sea. Eur. J. Phycol. 38: 223-231.

Piazzi L, Balata D, Cinelli F (2002) Epiphytic macroalgal assemblages of Posidonia oceanica rhizomes in the western Mediterranean. Eur. J. Phycol. 37: 69-76.

Piazzi L, Balata D, Ceccherelli G, Cinelli F (2001a) Comparative study of the growth of the two-occurring introduced green algae 
Caulerpa taxifolia and Caulerpa racemosa along the Tuscan coast (Italy, western Mediterranean). Cryptogamie, Algologie 22: 459-466.

Piazzi L, Ceccherelli G, Cinelli F (2001b) Threat to macroalgal diversity: effects of the introduced green alga Caulerpa racemosa in the Mediterranean. Mar. Ecol. Prog. Ser. 210: 149-159.

Pollard DA, Hutchings PA (1990) A review of exotic marine organisms introduced to the Australian Region. II. Invertebrates and algae. Asian Fish. Sci. 3: 223-250.

Reise K, Gollasch S, Wolff WJ (1999) Introduced marine species of the North Sea coasts. Helgol. Meeresunters. 52: 219-234.

Reise K, Gollasch S, Wolff WJ (2002) Introduced marine species of the North Sea coasts. In Leppäkoski E, Gollasch S, Olenin S (eds), Invasive Aquatic Species of Europe. Distribution, Impacts and Management, Kluwer Academic Publishers, Dordrecht, pp. 260-266.

Ribera Siguan MA (2002) Review of non-native marine plants in the Mediterranean Sea. In Leppäkoski E, Gollasch S, Olenin S (eds), Invasive Aquatic Species of Europe. Distribution, Impacts and Management, Kluwer Academic Publishers, Dordrecht, pp. 291-310.

Ribera Siguan MA (2003) Pathways of biological invasions of marine plants., In Ruiz GM, Carlton JT (eds), Invasive Species: Vectors and Management Strategies, Island Press, Washington, pp. 183-226.

Ruiz GM, Hewitt CL (2002) Toward understanding patterns of coastal marine invasions: A prospectus. In Leppäkoski E, Gollasch S, Olenin S (eds), Invasive Aquatic Species of Europe. Distribution, Impacts and Management, Kluwer Academic Publishers, Dordrecht, pp. 529-547.

Ruiz GM, Fofonoff PW, Carlton JT, Wonham MJ, Hines AH (2000) Invasion of coastal marine communities in North America: apparent patterns, processes, and biases. Annu. Rev. Ecol. Syst. 31: 481-531.

Saito Y (1975) Undaria. In Tokida J, Hirose H (eds), Advance of Phycology in Japan, Junk Publishers, The Hague, pp. 304-320.

Sant N, Delgado O, Rodriguez-Prieto C, Ballesteros E (1996) The spreading of the introduced seaweed Caulerpa taxifolia (Vahl) C. Agardh in the Mediterranean Sea: Testing the boat transportation hypothesis. Bot. Mar. 39: 427-430.

Schaffelke B, Deane D (2005) Desiccation tolerance of the introduced marine green alga Codium fragile ssp. tomentosoidesClues for likely transport vectors? Biological Invasions 7: 557-565.

Schaffelke B, Evers D, Walhorn A (1995) Selective grazing of the isopod Idotea baltica between Fucus evanescens and F. vesiculosus from Kiel Fjord (Western Baltic). Mar. Biol. 124: 215-218.

Schaffelke B, Murphy N, Uthicke S (2002) Using genetic techniques to investigate the sources of the invasive alga Caulerpa taxifolia in three new locations in Australia. Mar. Poll. Bull. 44: 204211.

Schaffelke B, Campbell ML, Hewitt CL (2005) Reproductive phenology of the introduced kelp Undaria pinnatifida (Phaeophyta, Laminariales) in Tasmania, Australia. Phycologia 44: 84-94.

Scheibling RE, Anthony SX (2001) Feeding, growth and reproduction of sea urchins (Strongylocentrotus droebachiensis) on single and mixed diets of kelp (Laminaria spp.) and the invasive alga Codium fragile ssp. tomentosoides. Mar. Biol. 139: 139-146.

Silva PC, Basson PW, Moe RL (1996) Catalogue of the Benthic Marine Algae of the Indian Ocean. University of California Publications in Botany 79. University of California Press, Berkeley.
Silva PC, Woodfield RA, Cohen AN, Harris LH, Goddard JHR (2002) First report of the Asian kelp Undaria pinnatifida in the northeastern Pacific Ocean. Biological Invasions 4: 333-338.

Simberloff D, von Holle B (1999) Positive interactions of nonindigenous species: invasional meltdown? Biological Invasions 1: 21-32.

Sinner J, Forrest B, Taylor M (2000) A strategy for managing the Asian kelp Undaria: Final report. Report to Ministry of Fisheries, New Zealand. Cawthron Report No. 578. Cawthron Institute, Nelson.

Smith JE, Hunter CL, Smith CM (2002) Distribution and reproductive characteristics of nonindigenous and invasive marine algae in the Hawaiian Islands. Pac. Sci. 56: 299-315.

Stimson J, Larned ST, Conklin E (2001) Effects of herbivory, nutrient levels, and introduced algae on the distribution and abundance of the invasive macroalga Dictyosphaeria cavernosa in Kaneohe Bay, Hawaii. Coral Reefs 19: 343-357.

Stockwell CA, Hendry AP, Kinnison MT (2003) Contemporary evolution meets conservation biology. Trends Ecol. Evol. 18: 94 101.

Thornber CS, Kinlan BP, Graham MH, Stachowicz JJ (2004) Population ecology of the invasive kelp Undaria pinnatifida in California: Environmental and biological controls on demography. Mar. Ecol. Prog. Ser. 268: 69-80.

Thresher RE (2000) Key threats from marine bioinvasions: a review of current and future issues. In Pederson J (ed.), Marine Bioinvasions, Proceedings of the First National Conference, January 24-27, 1999. Massachusetts Institute of Technology, Sea Grant College Program, Boston: pp. 24-36.

Trowbridge CD (1998) Ecology of the green macroalga Codium fragile (Suringar) Hariot 1889: Invasive and non-invasive subspecies. Oceanogr. Mar. Biol. Ann. Rev. 36: 1-64.

Valentine JP, Johnson CR (2003) Establishment of the introduced kelp Undaria pinnatifida in Tasmania depends on disturbance to native algal assemblages. J. Exp. Mar. Biol. Ecol. 295: 63-90.

Valentine JP, Johnson CR (2004) Establishment of the introduced kelp Undaria pinnatifida following dieback of the native macroalga Phyllospora comosa in Tasmania, Australia. Mar. Freshw. Res. 55: 223-230.

Van Beukering P, Cesar HSJ (2004) Ecological economic modeling of coral reefs: evaluating tourist overuse at Hanauma Bay and algae blooms at the Kihei Coast, Hawai'i. Pac. Sci. 58: 243-260.

Verlaque M (1989) Contribution a la flore des algues marines de Méditerranée: Especes rares ou nouvelles pour les côtes Françaises. Bot. Mar. 32: 101-113.

Verlaque M (2001) Checklist of the macroalgae of Thau Lagoon (Herault, France), a hot spot of marine species introduction in Europe. Oceanol. Acta 24: 29-49.

Verlaque M, Durand C, Huisman JM, Boudouresque C-F, Le Parco Y (2003) On the identity and origin of the Mediterranean invasive Caulerpa racemosa (Caulerpales, Chlorophyta). Eur. J. Phycol. 38: 325-339.

Verlaque M, Afonso-Carrillo J, Gil-Rodriguez M Candelaria, Durand C, Boudouresque CF, La Parco Y (2004) Blitzkrieg in a marine invasion: Caulerpa racemosa var. cylindracea (Bryopsidales, Chlorophyta) reaches the Canary Islands (NE Atlantic). Biological Invasions 6: 269-281.

Vitousek PM, Mooney HA, Lubchenco J, Melillo JM (1997) Human dominition of Earth's ecosystems. Science 277: 494-499.

Wallentinus I (1999a) Introduction and transfer of plants. In ALS Munro, SD Utting, I Wallentinus (eds), Status of introductions 
of non-indigenous marine species to north Atlantic waters 1981-1991. ICES Cooperative Research Report No. 231. International Council for the Exploration of the Sea, Copenhagen: pp. $1-32$.

Wallentinus I (1999b) Undaria pinnatifida. In Gollasch S, Minchin D, Rosenthal H, Voigt M (eds). Case Histories on Introduced Species: Their General Biology, Distribution, Range Expansion and Impact, Department of Fishery Biology, Institut for Marine Science, University of Kiel, Germany: pp. 11-19.

Wallentinus I (2002) Introduced marine algae and vascular plants in European aquatic environments. In Leppäkoski E, Gollasch S, Olenin S (eds), Invasive Aquatic Species of Europe. Distribution, Impacts and Management, Kluwer Academic Publishers, Dordrecht, pp. 27-52.

Watson KL, Cheney, DP Levine I (2000) Biomonitoring of an aquacultured introduced seaweed, Porphyra yezoensis (Rhodophyta, Bangiophycidae) in Cobscook Bay, Maine, USA. Marine Bioinvasions, Proceedings of the First National Conference, January 24-27, 1999. Massachusetts Institute of Technology, Sea Grant College Program, Boston: pp. 260-264.

Wilkinson DM (2004) The long history of biotic homogenization. Trends Ecol. Evol. 19: 283-284.

Williams SL, Schroeder SL (2004) Eradication of the invasive seaweed Caulerpa taxifolia by chlorine bleach. Mar. Ecol. Prog. Ser. 272: 69-76.

Williamson AT, Bax NC, Gonzalez E, Geeves W (2002) Development of a regional risk management framework for APEC economies for use in the control and prevention of introduced marine pests. APEC Secretariat, Technical Reports of the Marine Resource Conservation Working Group. CSIRO Centre for Research on Introduced Marine Pests, Hobart and InterAmerican Centre for Sustainable Ecosystems Development, Santiago.

Williamson MH, Fitter A (1996) The characteristics of successful invaders. Biol. Cons. 78: 163-170.

Wolff WJ, Reise K (2002) Oyster imports as a vector for the introduction of alien species into northern and western European coastal waters. In Leppäkoski E, Gollasch S, Olenin S (eds), Invasive Aquatic Species of Europe. Distribution, Impacts and Management, Kluwer Academic Publishers, Dordrecht, pp. 193 205.

Wotton DM, Hewitt CL (2004) Marine biosecurity post-border management: Developing incursion response systems for New Zealand. NZ J. Mar. Freshw. Res. 38: 553-559.

Wotton DM, O'Brien C, Stuart MD, Fergus DJ (2004) Eradication success Down Under: Heat treatment of a sunken trawler to kill the invasive seaweed Undaria pinnatifida. Mar. Poll. Bull. 49: 844-849.

Yoshida T, Nakajima Y, Nakata Y (1990) Check-list of marine algae of Japan (revised in 1990). Jpn. J. Phycol. 38: 269-320.

Zemke-White WL (2004) Assessment of the current knowledge on the environmental impacts of seaweed farming in the tropics. In: Phang et al. (eds), Marine Science into the New Millennium: New Perspectives and Challenges. Proceedings of the Asia-Pacific Marine Science and Technology Conference, 12-16 May 2002, Kuala Lumpur, Malaysia, 465-476. 